\title{
Spatial and temporal trend analysis of bovine brucellosis in Brazil, 2014 to 2018
}

\section{Análise espacial e temporal da brucelose bovina no Brasil, 2014 a 2018}

\author{
Claudia Mello Ribeiro ${ }^{1 *}$; Jonas Lotufo Brant de Carvalho ${ }^{2}$; Paula Andrea de Santis \\ Bastos $^{3}$; Rodrigo Guerrero Mendes ${ }^{4}$; Satie Katagiri5; Veruska Maia da Costa ${ }^{6}$
}

\section{Highlights:}

The incidence of bovine brucellosis in Brazil was estimated by state.

An analysis of temporal trends indicated a reduction in incidence in five states.

Spatial analysis revealed areas with high transmission rates of bovine brucellosis.

\begin{abstract}
Bovine brucellosis, a zoonotic disease endemic to Brazil, is a serious public health problem. It is a notifiable disease that, like tuberculosis, is regulated through a national control and eradication program. The epidemiological status of bovine brucellosis must be characterized in order to direct measures aimed at controlling the disease. This study focused on analyzing the spatial and temporal distribution of bovine brucellosis in Brazil. An ecological and time series study was conducted based on secondary data reported by the National Animal Health Information System for cases of bovine brucellosis diagnosed in Brazil (2014 - 2018). The gross and average incidence rate of brucellosis was estimated per state. Joinpoint regression was applied to calculate the annual percentage change (APC) in incidence and to identify states with significant trend changes. Spatial analysis of animals with brucellosis was performed using Kernel density estimation. A total of 19,631 animals with bovine brucellosis were confirmed, and the average incidence rate varied from 0.03 to 33.93/100,000 cattle in Brazil. The highest density of positive animals was found in the states of Santa Catarina and Paraná, which can be considered areas of greater transmission of Brucella abortus. Reductions in gross incidence rates were observed in Paraná (APC: $-13.2 ; 95 \%$ confidence interval [CI]: $-20.3--5.4 ; \mathrm{p}=0.01$ ), Rondônia (APC: $-44.7 ; 95 \% \mathrm{CI}$ : -62.0 - -19.4; $\mathrm{p}=0.01$ ), Mato Grosso do Sul (APC: $-59.0 ; 95 \%$ CI: $-77.7--24.5 ; \mathrm{p}=0.01$ ), Acre (APC: -40.0 ; 95\%CI: $-50.0--28.0 ; p=0.00$ ), and Ceará (APC: $-37.9 ; 95 \% C I:-50.9--21.4 ; p=0.00)$. The incidence rate significantly increased in Tocantins (APC: $122.1 ; 95 \% \mathrm{CI}: 4.5-372.2 ; \mathrm{p}=0.04$ ). The findings of this study will be helpful in guiding surveillance and prevention measures aimed at reducing the incidence of bovine brucellosis in Brazil.
\end{abstract}

Key words: Bovine brucellosis. Epidemiology. Kernel Map. Time series analysis. Zoonose.

\footnotetext{
${ }^{1}$ Prof $^{\mathrm{a}} \mathrm{Dr}^{\mathrm{a}}$, Universidade Nove de Julho, UNINOVE, São Paulo, SP, Brasil. E-mail: clau.mribeiro@hotmail.com

2 Prof. Dr., Universidade de Brasília, UnB, Brasília, DF, Brasil. E-mail: jonas.brant@gmail.com

3 Prof ${ }^{\mathrm{a}} \mathrm{Dr}^{\mathrm{a}}$, Universidade Metropolitana de Santos, UNIMES, Santos, SP, Brasil. E-mail: paulaasbastos@gmail.com

4 M.e, UNINOVE, São Paulo, SP, Brasil. E-mail: rodrigogm@uninove.br

5 Prof $^{\mathrm{a}} \mathrm{Dr}^{\mathrm{a}}$, Universidade Federal de Mato Grosso, UFMT, Barra do Garças, MT, Brasil. E-mail: sativet@gmail.com

6 M.e, Ministério da Saúde, MS, Brasília, DF, Brasil. E-mail: veruskamcosta@gmail.com

* Author for correspondence
} 


\section{Resumo}

A brucelose bovina é uma zoonose endêmica no Brasil, constituindo um grave problema de saúde pública. É uma doença de notificação obrigatória e regulamentada nacionalmente por programa de controle e erradicação em conjunto com a tuberculose. A caracterização da situação epidemiológica da brucelose bovina é um aspecto importante para direcionar as ações de controle desta zoonose. O objetivo deste estudo foi analisar a distribuição espacial e temporal da brucelose bovina no Brasil. Foi realizado um estudo ecológico e de séries temporais com base em dados secundários relatados pelo Sistema de Informação em Saúde Animal para casos de brucelose bovina diagnosticados no Brasil (2014 - 2018). A incidência bruta e média da brucelose por unidade federativa foi estimada. A regressão joinpoint foi aplicada para calcular a variação percentual anual (APC) da incidência e identificar as unidades federativas com mudanças significativas de tendência. A análise espacial dos animais com brucelose foi realizada usando a estimativa de densidade de Kernel. Foram confirmados 19.631 animais com brucelose bovina e a incidência média variou entre 0,03 a 33,93/100.000 bovinos no Brasil. A maior densidade de animais positivos foi observada nos estados de Santa Catarina e Paraná, considerados áreas de maior transmissão para Brucella abortus. Reduções nas taxas de incidência bruta foram observadas no Paraná (APC: -13.2; intervalo de confiança [IC]95\%: -20.3 - -5.4; p=0.01), Rondônia (APC: -44.7; IC95\%: -62.0 - -19.4; $\mathrm{p}=0.01$ ), Mato Grosso do Sul (APC: -59.0; IC95\%: -77.7 - -24.5; $\mathrm{p}=0.01$ ), Acre (APC: -40.0; IC95\%: -50.0 - -28.0; $\mathrm{p}=0.00$ ) e Ceará (APC: -37.9; IC95\%: -50.9 - -21.4; $\mathrm{p}=0.00$ ). Aumento significativo da tendência foi constatado em Tocantins (APC: 122.1; IC95\%: 4.5 $372.2 ; \mathrm{p}=0.04$ ). Espera-se que os resultados obtidos neste estudo auxiliem no direcionamento de ações de vigilância e de prevenção para reduzir a incidência da brucelose bovina no Brasil.

Palavras-chave: Análise de série temporal. Brucelose bovina. Epidemiologia. Mapa de Kernel. Zoonose.

\section{Introduction}

Brucellosis is a neglected zoonotic disease caused by the bacterium Brucella abortus. This pathogen is transmitted to humans mainly via: i) unpasteurized dairy, and undercooked or raw meat products; or (ii) by handling infected animals, aborted fetuses, or placenta (World Organisation for Animal Health [OIE], 2019a). In humans, brucellosis is mainly an occupational disease, and prevalent in countries of South and Central America, Africa, Asia, the Middle East, and the Mediterranean (Hasanjani Roushan \& Ebrahimpour, 2015).

This disease causes significant economic losses in the livestock industry, with negative effects on exports of dairy and meat products due to sanitary restrictions, which correspond to a non-tariff barrier to trade. Many countries have therefore implemented bovine brucellosis control and eradication programs (Ragan, Vroegindewey, \& Babcock, 2013; Zhang et al., 2018; OIE, 2019b).
In Brazil, the Ministry of Agriculture, Livestock and Food Supply (Ministério da Agricultura, Pecuária e Abastecimento [MAPA], 2001) established a National Program for the Control and Eradication of Animal Brucellosis and Tuberculosis (Programa Nacional de Controle e Erradicação da Brucelose e da Tuberculose Animal [PNCEBT]) in 2001 (MAPA, 2001). The purpose of the PNCEBT is to reduce the prevalence of brucellosis and bovine tuberculosis and eradicate them, and to promote the competitiveness of the national livestock industry. By 2016, the program had recommended a set of mandatory animal health measures such as the vaccination of 3- to 8-month-old female bovines with the B19 vaccine against brucellosis, the control of animal transportation, and the slaughter of brucellosis positive animals, in addition to encouraging the certification of brucellosis free farms. In 2017, the technical regulations of the PNCEBT were amended, allowing female bovines aged $\geq 3$ months to be vaccinated with the RB51 
strain (MAPA, 2017). However, cases of infected animals and herds have been reported in several Brazilian states and published in the MAPA's National Animal Health Information System.

Few epidemiological studies on this zoonotic disease in Brazil have been published so far. In view of the importance of characterizing the epidemiological status of bovine brucellosis in order to evaluate the effectiveness of measures established by the PNCEBT, since disease prevention in humans is tied to disease control in animals, the aim of this study was to analyze the spatial distribution of bovine brucellosis and its trends in Brazil.

\section{Materials and Methods}

Study area

This study was conducted in Brazil, the largest country in South America, which covers an area of $8,515,767 \mathrm{~km}^{2}$ and has an estimated population of 208,494,900. Brazil is a Federation composed of 26 states and a Federal District where the country's capital, Brasilia, is located. The country's states are grouped into five regions: North, Northeast, CentralWest, Southeast, and South (Figure 1). With an inventory of 214,899,796 cattle, Brazil's livestock sector is one of the country's main economic pillars, which is noted for its beef and dairy production (Table 1).

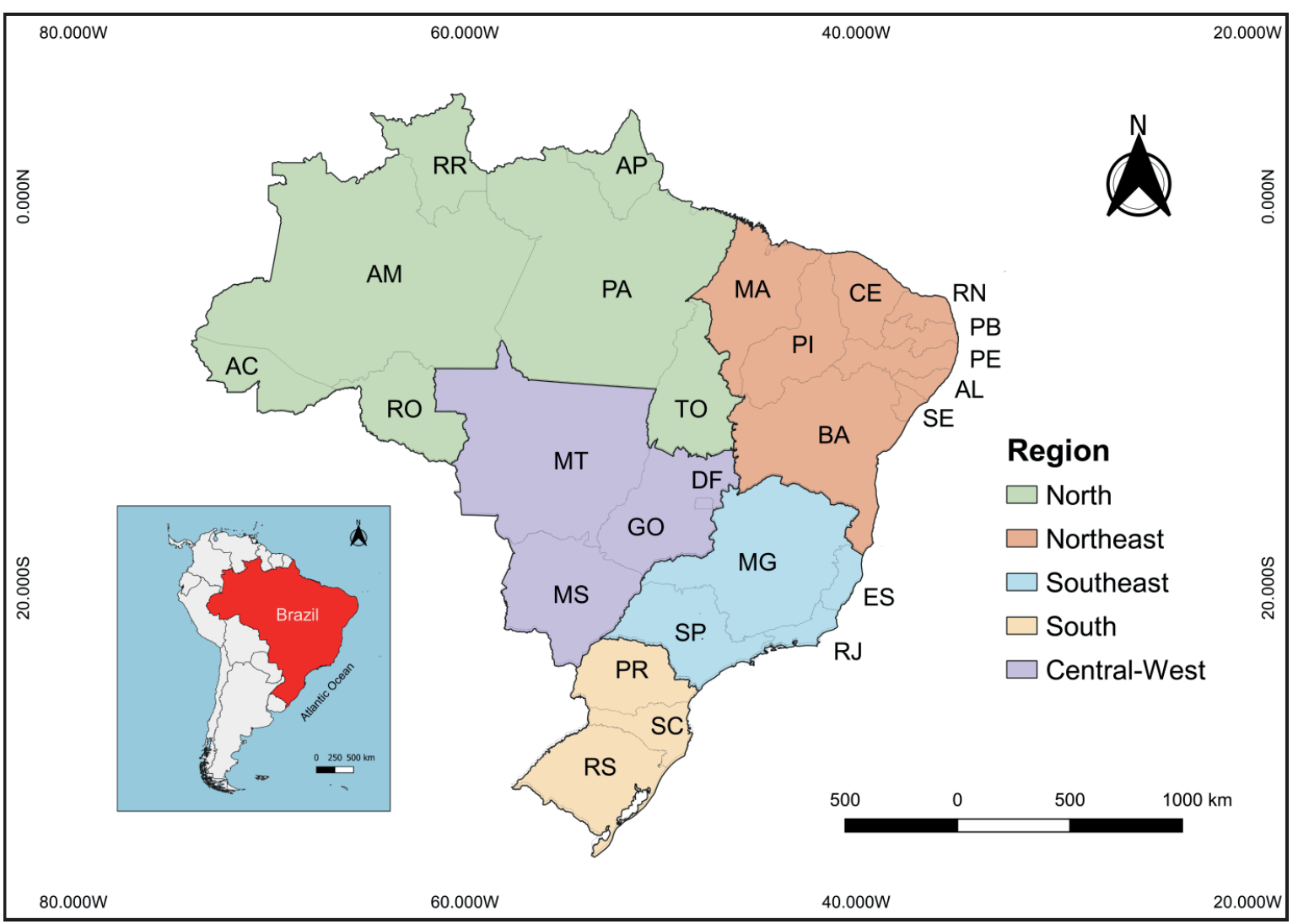

Figure 1. Geographic location of Brazil and division into five regions: Central-West (DF: Distrito Federal; GO: Goiás; MS: Mato Grosso do Sul; and MT: Mato Grosso), Northeast (AL: Alagoas; BA: Bahia; CE: Ceará; MA: Maranhão; PB: Paraíba; PE: Pernambuco; PI: Piauí; RN: Rio Grande do Norte; and SE: Sergipe), North (AC: Acre; AM: Amazonas; AP: Amapá; PA: Pará; RO: Rondônia; RR: Roraima; and TO: Tocantins), Southeast (ES: Espírito Santo; MG: Minas Gerais; RJ: Rio de Janeiro; and SP: São Paulo), and South (PR: Paraná; RS: Rio Grande do Sul; and SC: Santa Catarina). 
Table 1

Indicators of Brazil's livestock industry, 2014 to 2018

\begin{tabular}{|c|c|c|}
\hline State & $\begin{array}{c}\mathrm{N}^{\circ} \text { of slaughtered } \\
\text { cattle* }\end{array}$ & $\begin{array}{l}\text { Purchase of raw milk } \\
\text { (in thousands of liters) }\end{array}$ \\
\hline \multicolumn{3}{|l|}{ North region } \\
\hline Rondônia & $12,201,602$ & 1,257 \\
\hline Acre & $2,487,698$ & 197 \\
\hline Amazonas & $1,408,464$ & 151 \\
\hline Roraima & 260,913 & 99 \\
\hline Pará & $15,297,077$ & 651 \\
\hline Amapá & Missing data & Missing data \\
\hline Tocantins & $6,142,941$ & 637 \\
\hline \multicolumn{3}{|l|}{ Northeast region } \\
\hline Maranhão & $4,540,526$ & 442 \\
\hline Piauí & 788,066 & 138 \\
\hline Ceará & $1,189,262$ & 967 \\
\hline Rio Grande do Norte & 560,986 & 439 \\
\hline Paraíba & 398,114 & 475 \\
\hline Pernambuco & $1,744,267$ & 1,601 \\
\hline Alagoas & 906,440 & 585 \\
\hline Sergipe & 551,013 & 369 \\
\hline Bahia & $7,015,828$ & 2,271 \\
\hline \multicolumn{3}{|l|}{ Southeast region } \\
\hline Minas Gerais & $16,227,445$ & 10,625 \\
\hline Espírito Santo & $1,877,705$ & 772 \\
\hline Rio de Janeiro & $1,055,334$ & 1,957 \\
\hline São Paulo & $17,677,090$ & 3,237 \\
\hline \multicolumn{3}{|l|}{ South region } \\
\hline Paraná & $7,588,565$ & 3,369 \\
\hline Santa Catarina & $2,527,418$ & 2,061 \\
\hline Rio Grande do Sul & $11,061,674$ & 2,690 \\
\hline \multicolumn{3}{|l|}{ Central-West region } \\
\hline Mato Grosso do Sul & $19,848,484$ & 1,072 \\
\hline Mato Grosso & $27,874,530$ & 1,028 \\
\hline Goiás & $17,979,221$ & 2,867 \\
\hline Distrito Federal & Missing data & 152 \\
\hline
\end{tabular}

*Data from establishments under federal, state or municipal sanitary inspection; Source: IBGE. 
Study design

A retrospective ecological study was conducted based on bovine brucellosis cases reported in Brazil from 2014 to 2018. Secondary data from the National Animal Health Information System (http:// indicadores.agricultura.gov.br/saudeanimalen/ index.htm) were used to obtain the variables of interest, namely, the number of positive animals, number of infected herds, state, and year of notification. Cattle inventory data were obtained from the Brazilian Institute of Geography and Statistics (IBGE).

\section{Statistical and spatial analysis}

The gross and average incidence rate of bovine brucellosis was estimated for the period of 2014 to 2018. The gross incidence rate was calculated by dividing the total number of new cases by the total number of cattle in a state, multiplied by 100,000 cattle. Poisson regression was used to analyze temporal trends. The annual percentage change (APC) and its respective 95\% confidence interval were calculated. A value of $\mathrm{p}<0.05$ was considered statistically significant. Regression analysis was performed using the Joinpoint Regression Program, version 4.7.0.0 (http://surveillance.cancer.gov/ joinpoint/) (Kim, Fay, Feuer, \& Midthune, 2000).

Areas exhibiting the highest number of cases of bovine brucellosis per square meter of surface area were visually identified using the kernel density estimator with the quartic function. A search radius of $750,000 \mathrm{~m}$ was used to create the kernel density map (Carvalho \& Souza-Santos, 2005). The digital maps were obtained from shapefiles in the cartographic database of the IBGE, while the thematic maps were created using TerraView version 4.2.2 and QGIS version 3.6 software.

\section{Ethical considerations}

This study was based on public domain data, dispensing with the need for approval from a research ethics board.

\section{Results and Discussion}

This study analyzed the spatial and temporal distribution of bovine brucellosis in Brazil based on annual notifications to identify priority areas for the implementation of prophylactic measures. From 2014 to 2018, 3,350 infected herds and 19,631 animals with bovine brucellosis were reported in Brazil. The country's southern region showed a larger number of infected herds. i.e., Paraná, with 1,537 herds and Santa Catarina, with 567 herds positive for brucellosis (Figure 2). However, 7,405 cases of brucellosis were reported in Santa Catarina, 4,875 were reported in Paraná and 1,778 were reported in Rio Grande do Sul (Figure 3). 


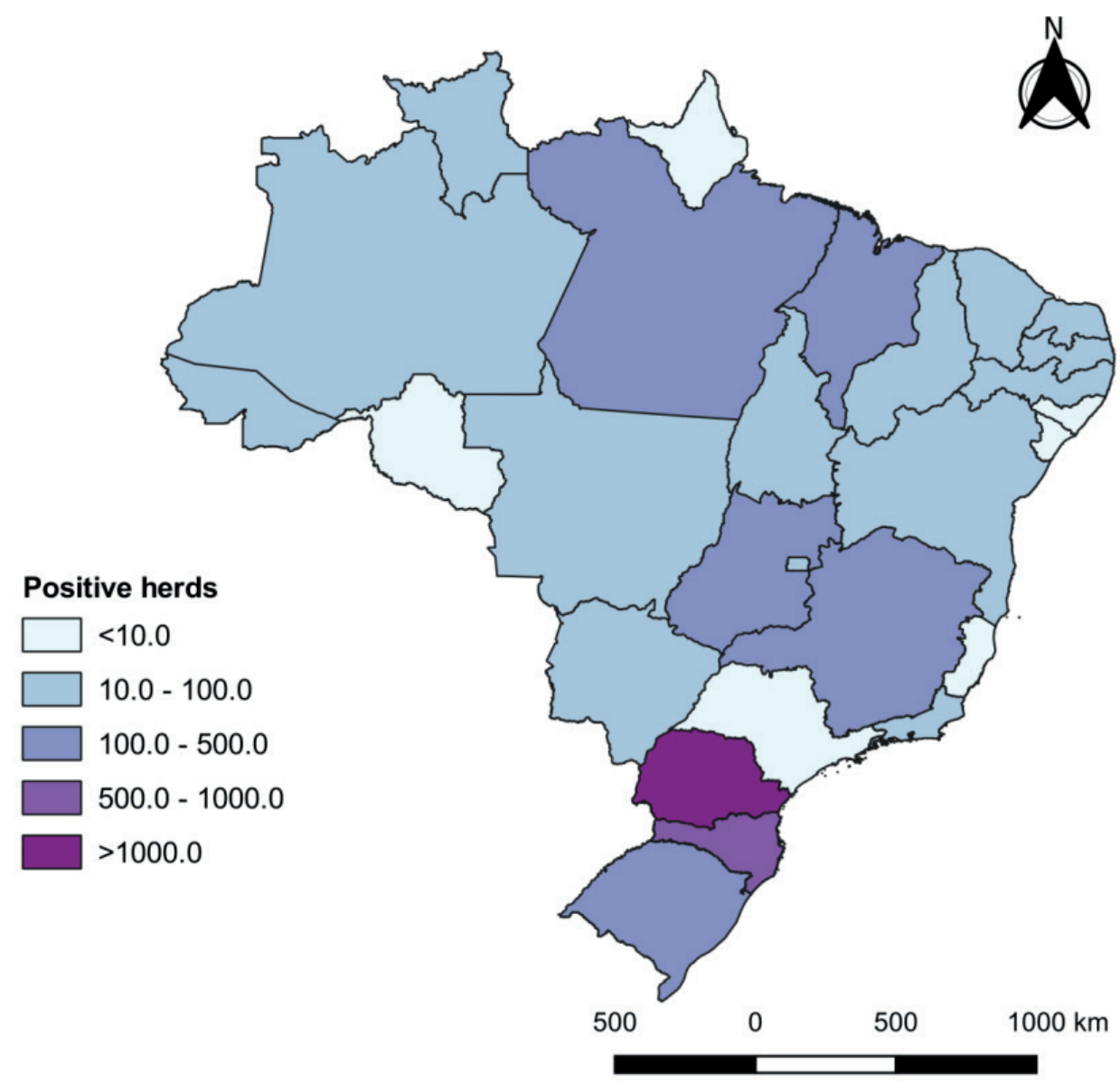

Figure 2. Spatial distribution of herds positive for bovine brucellosis in Brazil, by state, 2014 to 2018.

The average incidence of brucellosis in the country was 3.43 per 100,000 cattle. The average incidence was low in most states (less than 1.0/100,000 cattle); the lowest average incidence was found in the state of Rondônia (0.03) and the highest was found in Santa Catarina (33.93) (Figure 4). Joinpoint regression analysis indicated that there was no statistically significant change in the incidence rate in the state of Santa Catarina (APC: $5.8 ; 95 \%$ confidence interval [CI]: -32.4 $65.8 ; \mathrm{p}=0.71$ ). Over time, there was a statistically significant decline in incidence rates in the states of Paraná (APC: -13.2; 95\%CI: -20.3 - -5.4; $\mathrm{p}=0.01$ ), Rondônia (APC: -44.7 ; 95\%CI: -62.0 -19.4; $\mathrm{p}=0.01$ ), Mato Grosso do Sul (APC: -59.0 ; 95\%CI:-77.7 - 24.5; $\mathrm{p}=0.01$ ), Acre (APC: -40.0 ; 95\%CI: $-50.0-28.0 ; \mathrm{p}=0.00$ ), and Ceará (APC: -37.9 ; 95\%CI: $-50.9--21.4 ; \mathrm{p}=0.00)$. However, the incidence rate in the state of Tocantins increased significantly during the period 2014 to 2018 (APC $=122.1$; 95\%CI: 4.5 - 372.2; $\mathrm{p}=0.04$ ) (Table 2). 


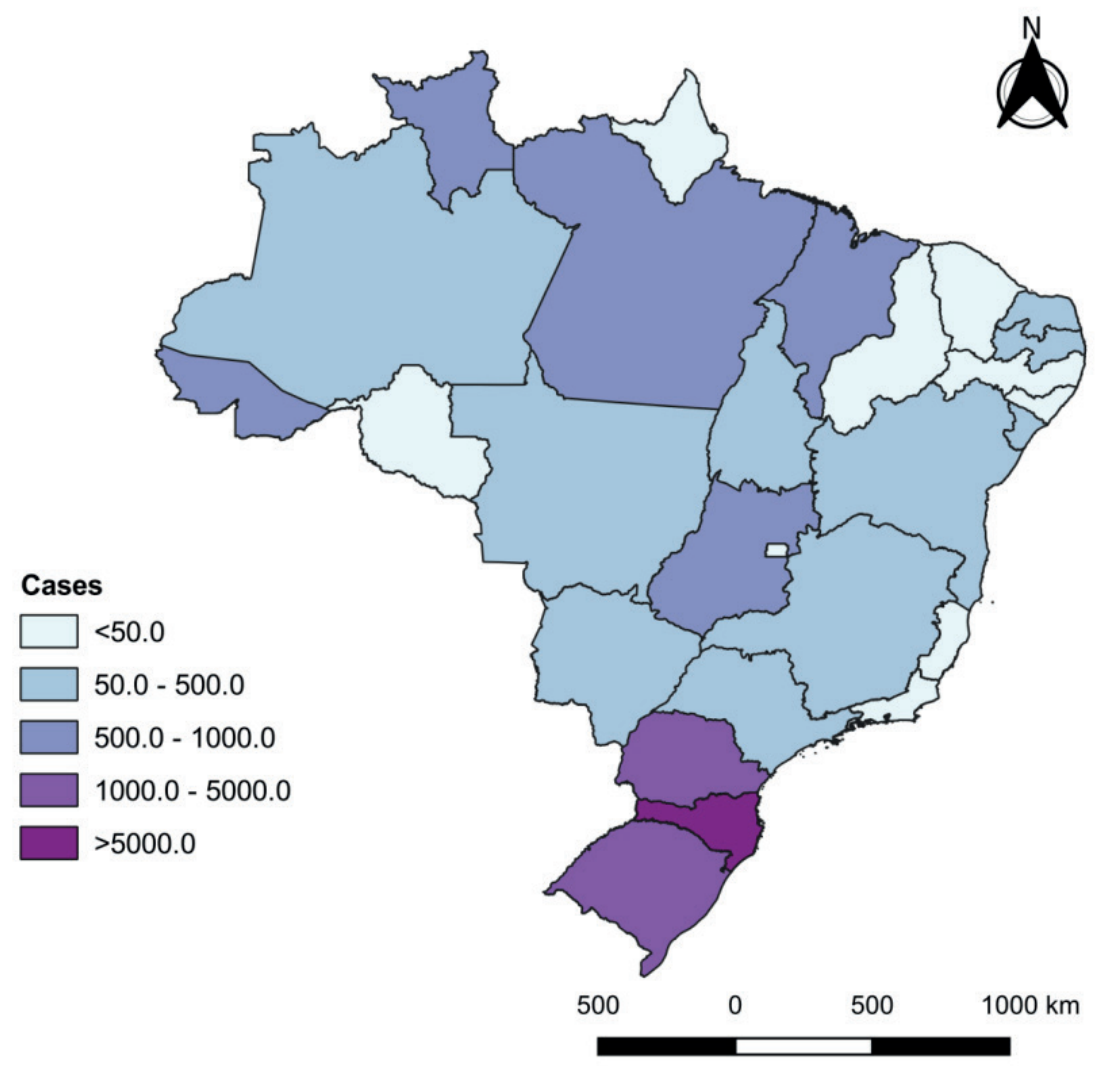

Figure 3. Spatial distribution of bovine brucellosis cases in Brazil, by state, 2014 to 2018.

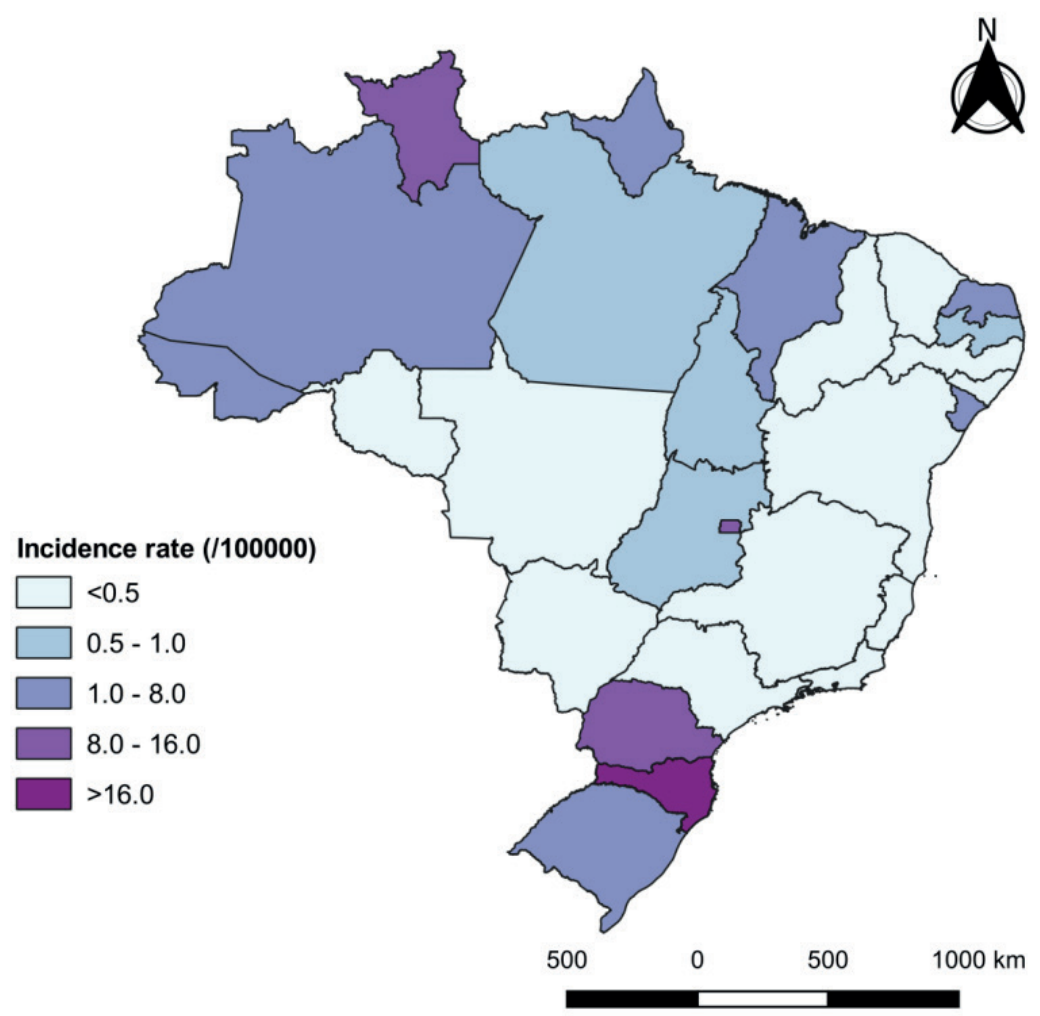

Figure 4. Spatial distribution of the average incidence of bovine brucellosis per 100,000 cattle in Brazil, 2014 to 2018. 
Table 2

Joinpoint regression analysis of temporal trends of bovine brucellosis incidence in Brazil, 2014 to 2018

\begin{tabular}{|c|c|c|c|c|c|c|c|c|c|}
\hline \multirow{2}{*}{ State } & \multicolumn{5}{|c|}{ Incidence per 100,000 cattle } & \multirow{2}{*}{ APC } & \multirow{2}{*}{$95 \% \mathrm{CI}$} & \multirow{2}{*}{$\mathrm{p}$ - value } & \multirow{2}{*}{ Trend } \\
\hline & 2014 & 2015 & 2016 & 2017 & 2018 & & & & \\
\hline \multicolumn{10}{|l|}{ North region } \\
\hline Rondônia & 0.07 & 0.04 & 0.02 & 0.00 & 0.00 & -44.7 & $-62.0--19.4$ & 0.01 & Decreasing \\
\hline Acre & 8.60 & 6.41 & 3.03 & 1.88 & 1.04 & -40.0 & $-50.0--28.0$ & 0.00 & Decreasing \\
\hline Amazonas & 5.76 & 2.93 & 1.44 & 2.53 & 0.07 & -32.2 & $-61.2-18.6$ & 0.11 & Stationary \\
\hline Roraima & 21.19 & 9.56 & 1.02 & 4.06 & 36.70 & 20.9 & $-37.4-133.5$ & 0.42 & Stationary \\
\hline Pará & 1.58 & 0.69 & 1.09 & 0.28 & 0.51 & -25.1 & $-51.1-14.8$ & 0.12 & Stationary \\
\hline Amapá & 4.77 & 0.00 & 0.00 & 0.00 & 11.95 & -0.0 & $-52.3-109.6$ & 0.99 & Stationary \\
\hline Tocantins & 0.17 & 0.04 & 0.02 & 0.46 & 1.92 & 122.1 & $4.5-372.2$ & 0.04 & Increasing \\
\hline \multicolumn{10}{|l|}{ Northeast region } \\
\hline Maranhão & 3.15 & 5.66 & 0.67 & 1.30 & 0.58 & -36.4 & $-73.9-55.0$ & 0.20 & Stationary \\
\hline Piauí & 0.18 & 0.18 & 0.00 & 0.12 & 1.66 & 93.9 & $-11.0-322.1$ & 0.07 & Stationary \\
\hline Ceará & 0.46 & 0.39 & 0.16 & 0.13 & 0.08 & -37.9 & $-50.9--21.4$ & 0.00 & Decreasing \\
\hline Rio Grande do Norte & 7.29 & 1.41 & 4.04 & 1.37 & 0.34 & -42.2 & $-70.5-13.5$ & 0.08 & Stationary \\
\hline Paraíba & 1.65 & 0.93 & 0.58 & 0.49 & 1.16 & -10.3 & $-41.0-36.4$ & 0.46 & Stationary \\
\hline Pernambuco & 0.1 & 0.15 & 0.21 & 0.72 & 0.33 & 46.3 & $-32.3-215.9$ & 0.21 & Stationary \\
\hline Alagoas & 0.07 & 0.00 & 1.16 & 0.00 & 0.00 & 23.8 & $-94.4-2651.8$ & 0.84 & Stationary \\
\hline Sergipe & 2.13 & 3.41 & 0.16 & 0.09 & 0.56 & -35.7 & $-78.1-88.8$ & 0.28 & Stationary \\
\hline Bahia & 0.32 & 0.06 & 0.00 & 0.00 & 1.48 & 54.4 & $-19.7-196.9$ & 0.12 & Stationary \\
\hline \multicolumn{10}{|l|}{ Southeast region } \\
\hline Minas Gerais & 0.74 & 0.51 & 0.19 & 0.38 & 0.28 & -23.5 & $-43.6-3.8$ & 0.06 & Stationary \\
\hline Espírito Santo & 0.39 & 0.13 & 0.09 & 0.61 & 0.05 & 2.0 & $-58.9-153.0$ & 0.94 & Stationary \\
\hline Rio de Janeiro & 0.00 & 0.21 & 0.66 & 0.43 & 0.23 & 3.4 & $-65.1-206.1$ & 0.92 & Stationary \\
\hline São Paulo & 0.55 & 0.00 & 0.98 & 0.00 & 0.09 & -3.6 & $-69.6-205.3$ & 0.92 & Stationary \\
\hline \multicolumn{10}{|l|}{ South region } \\
\hline Paraná & 14.04 & 11.81 & 9.13 & 9.87 & 7.38 & -13.2 & $-20.3--5.4$ & 0.01 & Decreasing \\
\hline Santa Catarina & 13.15 & 47.50 & 35.07 & 35.41 & 38.50 & 5.8 & $-32.4-65.8$ & 0.71 & Stationary \\
\hline Rio Grande do Sul & 2.63 & 2.06 & 2.31 & 3.05 & 3.02 & 5.4 & $-8.9-21.9$ & 0.33 & Stationary \\
\hline \multicolumn{10}{|l|}{ Central-West region } \\
\hline Mato Grosso do Sul & 0.9 & 0.00 & 0.16 & 0.06 & 0.01 & -59.0 & $-77.7--24.5$ & 0.01 & Decreasing \\
\hline Mato Grosso & 0.05 & 0.13 & 0.01 & 0.01 & 0.07 & -11.5 & $-60.9-100.5$ & 0.66 & Stationary \\
\hline Goiás & 0.73 & 0.93 & 0.21 & 0.32 & 0.39 & -20.1 & $-49.4-25.9$ & 0.21 & Stationary \\
\hline Distrito Federal & 15.99 & 5.17 & 6.23 & 12.88 & 2.14 & -18.3 & $-57.5-56.9$ & 0.39 & Stationary \\
\hline
\end{tabular}

APC: annual percent change; $95 \% \mathrm{CI}$ : 95\% confidence interval.

Figure 5 shows the kernel density map, where the areas with the largest number of cases are highlighted in red. The highest density of brucellosis-positive animals was detected in the states of Santa Catarina and Paraná.
Santa Catarina was the seventh largest milk producer in the country (Table 1), but had the highest number of positive animals and a high average incidence of brucellosis, with a stationary trend. 
To date, there are very few published studies regarding the distribution of bovine brucellosis in the state of Santa Catarina. In 2001, Sikusawa et al. (2009) conducted a seroepidemiological survey of bovine brucellosis and found a low prevalence of infected animals (0.06\%). For this reason, the MAPA cancelled the mandatory vaccination of female bovines with the B19 vaccine in the state of Santa Catarina, as a strategy to eradicate brucellosis. However, the MAPA allows the RB51 vaccine to be used in females of infected herds or at farms choosing to vaccinate the herd as a preventive measure (MAPA, 2004; Secretaria de Estado da Agricultura e da Pesca de Santa Catarina [SAR], 2012, 2017). In 2012, a study was conducted to ascertain if the prevalence of bovine brucellosis in Santa Catarina was still low. Among 8,630 cows that were tested, 16 were positive, indicating a low prevalence of infected animals $(1.21 \%)$. The study concluded that the state should maintain the ban on the B19 vaccine and apply eradication strategies based on the surveillance system for the detection and certification of brucellosis-free herds (Baumgarten et al., 2016).

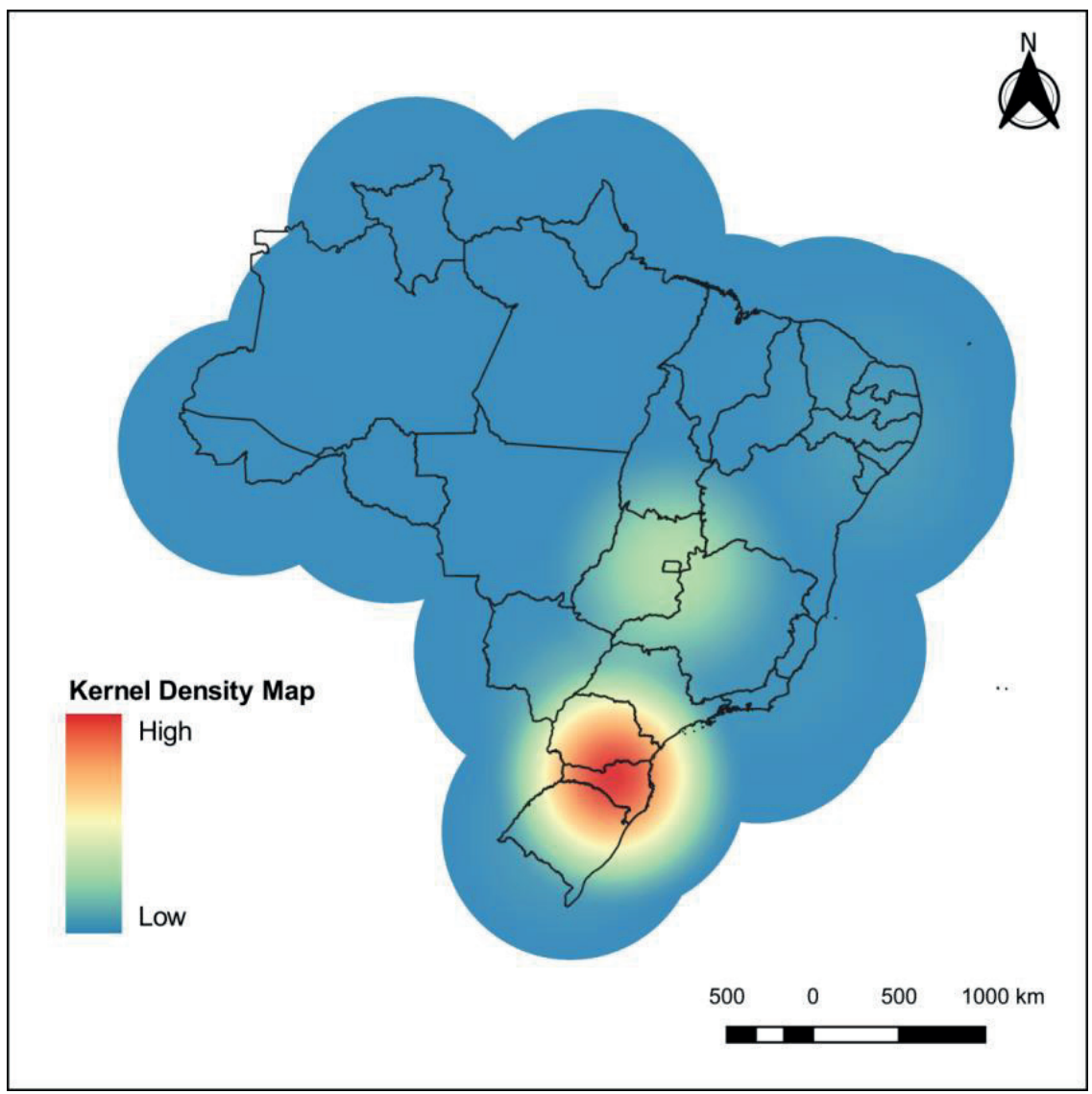

Figure 5. Kernel density map showing the distribution of animals with bovine brucellosis in Brazil, 2014 to 2018.

However, the results of this study indicated that Santa Catarina was characterized as an area of high priority intervention against bovine brucellosis. Therefore, the surveillance system should be improved and new studies examining the prevalence/ incidence of brucellosis should be carried out to better understand the epidemiology and improve preventive measures against this zoonotic disease in this region. 
The state of Paraná was the second largest milk producer in Brazil (Table 1) and had a large number of infected herds $(1,537)$, with a high density of animals with bovine brucellosis. Information concerning the distribution of brucellosis in the state of Paraná is scarce. An investigation conducted in 2002 showed that $1.7 \%$ of sampled animals were positive (Dias et al., 2009).

In the present study, the incidence of brucellosis in the state of Paraná was found to decrease during the period 2014 to 2018. This finding confirms that the brucellosis control strategies implemented there have been successful. The state of Paraná established the following brucellosis control strategies: i) mandatory and proven vaccination of female bovines with vaccine strains B19 or RB51; ii) application of fines to producers that do not vaccinate their animals and mandatory updating of vaccination schedules (Agência de Defesa Agropecuária do Paraná [ADAPAR], 2013); and (iii) a ban on the receipt and sale of milk from farms that do not present annual negative test results of their herds and proof of vaccination against brucellosis (ADAPAR, 2017).

Rondôniaand Mato Grosso do Sulwere prominent for their beef production between 2014 and 2018 (Table 1), and their brucellosis incidence rates decreased significantly during this period (Table 2). This can be explained by the mandatory vaccination program against brucellosis implemented by the Animal Health departments of these states (Agência de Defesa Sanitária Agrosilvopastoril do Estado de Rondônia [IDARON], 2010; Agência Estadual de Defesa Sanitária Animal e Vegetal do Mato Grosso do Sul [IAGRO], 2014). After the implementation of this preventive measure, surveys revealed a decrease in the prevalence of bovine brucellosis in both regions. In 2004, the prevalence of brucellosis in Rondônia was 6.2\% (Villar et al., 2009). A decade later, Inlamea et al. (2016) evaluated the outcome of the aforementioned vaccination program and found a significant reduction in the prevalence of infected animals (1.9\%). In Mato Grosso do Sul, the effectiveness of the bovine brucellosis vaccination program was evaluated based on the reduction of infected herds, whose prevalence rate in 2003 was $41.5 \%$, and by 2009 had declined to $30.6 \%$ (Chate et al., 2009; Leal et al., 2016).

During the study period, the incidence of bovine brucellosis in Tocantins was low $(0.5 \%)$, but showed an increasing trend. Proven vaccination against brucellosis is still mandatory in Tocantins, and producers that fail to vaccinate their animals are fined (Agência de Defesa Agropecuária do Estado de Tocantins [ADAPEC], 2014). Since 2017, farmers in Tocantins have vaccinated more than 95\% of female bovines, which exceeds MAPA's target of $80 \%$ vaccination coverage (ADAPEC, 2019). In view of the above, new surveys are needed to determine the risk factors related to the increased incidence of bovine brucellosis in Tocantins.

\section{Conclusions}

In conclusion, the prevalence of bovine brucellosis during the study period varied among Brazilian states. Incidence rates in most states were low, indicating that the recommendations of the PNCEBT are producing satisfactory results. Spatial analysis pointed to Santa Catarina and Paraná as areas with the highest transmission rates of brucellosis in Brazil. However, the analysis of incidence trends indicated that Paraná has made advances in the control of brucellosis. The recommendations of the PNCEBT in Brazilian states must be enforced, since the presence of brucellosis in endemic areas represents a threat to human health.

\section{References}

Agência de Defesa Agropecuária do Estado de Tocantins (2014). Portaria $n^{\circ} 279$ de 31 de julho de 2014. Recuperado de https://central3.to.gov.br/ arquivo/264614/ 
Agência de Defesa Agropecuária do Estado de Tocantins (2019). Informações e dados epidemiológicos. Recuperado de https://adapec.to.gov.br/animal/ sanidade-animal/programa-estadual-de-controle-eerradicacao-da-brucelose-e-tuberculose---pecebt/ informacoes-e-dados-epidemiologicos/

Agência de Defesa Agropecuária do Paraná (2013). Portaria ADAPAR $n^{\circ} 344$ de 17 de outubro de 2013. Recuperado de http://www.adapar.pr.gov.br/ modules/faq/index.php

Agência de Defesa Agropecuária do Paraná (2017). Portaria $n^{\circ} 133$ de 26 de maio de 2017. Recuperado de http://www.adapar.pr.gov.br/arquivos/File/ GABINETE/PORTARIAS/2017/133_17.pdf

Agência de Defesa Sanitária Agrosilvopastoril do Estado de Rondônia (2010). Portaria ${ }^{\circ} 65$ de 19 de fevereiro de 2010. Recuperado de http://www.idaron.ro.gov. br/wp-content/uploads/2018/10/Portaria_ 65-2010. pdf

Agência Estadual de Defesa Sanitária Animal e Vegetal do Mato Grosso do Sul (2014). Portaria IAGRO $n^{\circ}$ 3041 de 31 de janeiro de 2014. Recuperado de http:// www3.servicos.ms.gov.br/iagro_ged/pdf/2262 GED.pdf

Baumgarten, K. D., Veloso, F. P., Grisi, J. H. H., Fo., Ferreira, F., Amaku, M., Dias, R.,... A., Ferreira, J. S., Neto. (2016). Prevalência e fatores de risco para brucelose bovina no estado de Santa Catarina, Brasil. Semina: Ciências Agrárias, 37(5), 3425-3436. doi: 10.5433/1679-0359.2016v37n5Supl2p3425

Carvalho, M. S., \& Souza-Santos, R. (2005). Analysis of spatial data in public health: methods, problems, and perspectives. Cadernos Saúde Pública, 21(2), 361378. doi: 10.1590/S0102-311X2005000200003

Chate, S. C., Dias, R. A., Amaku, M., Ferreira, F., Moraes, G. M., Costa, A. A., Neto,... Ferreira, J. S., Neto. (2009). Situação epidemiológica da brucelose bovina no Estado do Mato Grosso do Sul. Arquivo Brasileiro de Medicina Veterinária e Zootecnia, 61(Suppl.1), 46-55. doi: 10.1590/S0102-09352009000700007

Dias, J. A., Müller, E. E., Dias, R. A., Freitas, J. C., Amaku, M., Ferreira, F.,... Ferreira, J. S., Neto. (2009) Situação epidemiológica da brucelose bovina no Estado do Paraná. Arquivo Brasileiro de Medicina Veterinária e Zootecnia, 61(Suppl. 1), 6676. doi:10.1590/S0102-09352009000700009

Hasanjani Roushan, M. R., \& Ebrahimpour, S. (2015). Human brucellosis: an overview. Caspian Journal of Internal Medicine, 6(1), 46-47.
Inlamea, O. F., Rocha, A. B., Ferreira, F., Grisi, J. H. H., $F^{o}$., Heinemann, M. B., Dias, R. A.,... Ferreira, J. S., Neto. (2016). Effect of vaccination in lowering bovine brucellosis in the State of Rondônia, Brazil. Semina: Ciências Agrárias, 37(5), 3493-3504. doi: 10.5433/1679-0359.2016v37n5Supl2p3493

Kim, H. J., Fay, M. P., Feuer, E. J., \& Midthune, D. N. (2000). Permutation tests for joinpoint regression with applications to cancer rates. Statistics in Medicine, 19(3), 335-351. doi: 10.1002/(sici)10970258(20000215)19:3<335::aid-sim336>3.0.co;2-z

Leal, J. M., Fo., Bottene, I. F. N., Monteiro, L. A. R. C., Pellegrin, A. O., Gonçalves, V. S. P., Ferreira, F.,... Ferreira, J. S., Neto. (2016). Control of bovine brucellosis from 1998 to 2009 in the State of Mato Grosso do Sul, Brazil. Semina: Ciências Agrárias, 37(5), 3467-3478. doi: 10.5433/1679-0359.2016v37n5Sup12p3467

Ministério da Agricultura Pecuária e Abastecimento (2001). Instrução Normativa $n^{\circ} 2$, de 10 de janeiro de 2001. Recuperado de http://sistemasweb.agricultura. gov.br/sislegis/action/detalhaAto.do?method $=$ consultarLegislacaoFederal

Ministério da Agricultura Pecuária e Abastecimento (2004). Portaria $n^{\circ} 11$, de 26 de janeiro de 2004. Recuperado de http://sistemasweb.agricultura.gov. $\mathrm{br} /$ sislegis/action/detalhaAto.do? $\mathrm{method}=$ onsultar LegislacaoFederal

Ministério da Agricultura Pecuária e Abastecimento (2017). Instrução Normativa SDA $n^{\circ} 10$, de 3 de março de 2017. Recuperado de http://www. agricultura.gov.br/assuntos/sanidade-animal-evegetal/saude-animal/programas-de-saude-animal/ brucelose-e-tuberculose/1IN102017.pdf

Ragan, V., Vroegindewey, G., \& Babcock, S. (2013). International standards for brucellosis prevention and management. Revue scientifique et technique / Office international des épizooties, 32(1), 189-198. doi: 10.20506/rst.32.1.2203

Secretaria de Estado da Agricultura e da Pesca de Santa Catarina (2012). Portaria $n^{\circ} 17$, de 20 de julho de 2012. Recuperado de http://www.cidasc.sc.gov.br/ defesasanitariaanimal/files/2019/07/PORTARIASAR-17-2012-de-20-07-2012.pdf

Secretaria de Estado da Agricultura e da Pesca de Santa Catarina (2017). Portaria $n^{\circ} 19$, de 31 de julho de 2017. Recuperado de http://www.cidasc.sc.gov.br/ defesasanitariaanimal/files/2017/01/PORTARIA19.2017-ALTERA-ART.-8-REG.-BRUCELOSE-ETUBERCULOSE.pdf 
Sikusawa, S., Amaku, M., Dias, R. A., Ferreira, J. S., Neto, Martins, C., Gonçalves, V. S. P.,... Ferreira, F. (2009). Situação epidemiológica da brucelose bovina no Estado de Santa Catarina. Arquivo Brasileiro de Medicina Veterinária e Zootecnia, 61(Suppl. 1), 103-108. doi: 10.1590/S0102-09352009000700013

Villar, K. S., Amaku, M., Dias, R. A., Ferreira, J. S., Neto, Benitez, F., Gonçalves, V. S. P.,... Ferreira, F. (2009). Situação epidemiológica da brucelose bovina no Estado de Rondônia. Arquivo Brasileiro de Medicina Veterinária e Zootecnia, 61(Suppl. 1), 85-92. doi: 10.1590/S0102-09352009000700011

World Organisation for Animal Health (2019a). Brucellosis. Recuperado de http://www.oie.int/ en/animal-health-in-the-world/animal-diseases/ brucellosis/
World Organisation for Animal Health (2019b). Terrestrial animal health code. Recuperado de http://www.oie.int/standard-setting/terrestrial-code/ access-online/

Zhang, N., Huang, D., Wu, W., Liu, J., Liang, F., Zhoum B., \& Guanm, P. (2018). Animal brucellosis control or eradication programs worldwide: A systematic review of experiences and lessons learned. Preventive Veterinary Medicine, 160(Suppl. 1), 105-115. doi: 10.1016/j.prevetmed.2018.10.002 